\title{
Erythrocytes in Human Transplantation: Effects of Pretreatment with ABO Group-Specific Antigens
}

\author{
F. T. Rapaport, J. Dausset, L. Legrand, A. Barge, \\ H. S. Lawrence, and J. M. Converse \\ From the Department of Surgery and Institute of Reconstructive Plastic \\ Surgery, New York University Medical Center, New York 10016; and \\ the Institut de Recherches sur les Maladies du Sang, \\ Hôpital Saint-Louis, University of Paris, France
}

\begin{abstract}
A в S T R A C T Erythrocyte group antigens A and $B$ can act as potent and group-specific transplantation antigens in man. ABO group-incompatible recipients pretreated with such antigens have rejected skin allografts obtained from donors incompatible for the same antigens in an accelerated (4-5 days) or white graft manner. Skin grafts applied to the same recipients from $\mathrm{ABO}-$ compatible donors were accorded first-set survival times. Intact erythrocyte suspensions and antigens isolated from hog ( $A$ substance) and horse ( $B$ substance) stomachs, were equally capable of inducing this type of allograft sensitivity. The latter observation broadens the spectrum of heterologous antigens capable of inducing allograft sensitivity in the mammalian host and provides a readily available, heat-stable, and water-soluble source of antigens for further studies of allograft rejection mechanisms in man.
\end{abstract}

\section{INTRODUCTION}

Erythrocyte groups were first implicated in human transplantation in 1919 by Shawan's report that the use of blood grouping principles in skin grafting could result in prolonged allograft survival (1). The exact role of such antigens in conditioning allograft responses has, however, remained obscure

A partial report of this work was read at the 53rd Annual Clinical Congress of the American College of Surgeons, 2 October 1967.

Received for publication 5 February 1968 and in revised form 9 May 1968. for some years (2). The studies of Brown and McDowell (3) and of Woodruff and Allan (4) appeared to indicate that blood groups were of no particular significance in conditioning the rejection of skin allografts in man. In addition, Medawar $(5,6)$ provided cogent evidence that erythrocytes were not active as individual- or strain-specific transplantation antigens in experimental animals. In a different experimental setting, however, Barrett and Hansen (7) showed that erythrocyte stromata could sensitize mice to tumor transplants. More recently, Griffiths and Crikelair (8) and Kuhns, Rapaport, Lawrence, and Converse (9) described anti-A and/or anti-B antibody responses in human recipients of transplantation antigens (skin graft, leukocyte extracts) obtained from $\mathrm{ABO}$-incompatible donors, once again implicating erythrocyte antigens in experimental allograft responses.

The possibility that erythrocyte antigens might also be of importance in organ transplantation was initially noted by Simonsen and Sorensen and Simonsen, Buemann, Gammeltoft, Jensen, and Jorgensen (10-12), who suggested as early as 1949 that the sharing of antigens by kidneys and erythrocytes indicated that gross biological incompatibilities between donor and recipient might be eliminated by avoidance of incompatibilities in the $\mathrm{ABO}$ group antigens. It is of interest in this regard that original reports by Hume, Merrill, Miller, and Thorn (13) of renal transplantation in man included one blood group $\mathrm{O}$ recipient of a 
transplant obtained from a group B donor. This transplant ceased to function on the 7 th postoperative day, and, although other variables were also implicated, the authors concluded that renal transplantation would be unwise in the face of major blood group incompatibilities. This observation has influenced Hume et al.'s selection of donors and recipients for renal transplantation since that time (14-17). Woodruff (18), Hamburger, Vaysse, Crosnier, Aubert, and Dormont (19), Goodwin, Mims, and Kaufman (20), and Murray and Harrison (21) have also expressed support for the concept that renal allografts should not be performed across major ABO blood group incompatibility barriers. It was not, however, until the carefully documented clinical studies of Starzl et al. (22-25) that the influence of $A B O$ group incompatibility upon the fate of human renal allografts became fully established: Kidneys transplanted across major ABO group barriers were shown to risk a particularly rapid and violent type of rejection, whose tempo and intensity were related to a significant extent to pretransplantation anti-A or anti-B isoantibody titers in the recipients (26). A recent report of the Kidney Transplant Registry fully confirms this concept (27), and the observations of Jacobson and Najarian (28) that pretreatment of dogs with serologically incompatible erythrocytes may induce in the recipients a decrease in survival times of kidney transplants obtained from donors of the same erythrocyte group suggests that some form of isosensitization may have been implicated in the mediation of such responses.

It is the purpose of this study to assess the role of erythrocyte group antigens in human transplantation under experimental conditions designed to delineate the circumstances under which such antigens might be capable of inducing rapid allograft rejection. In preliminary experiments, blood group $\mathrm{O}$ recipients immunized with $\mathrm{AB}$ erythrocytes were noted to reject skin allografts obtained from other donors belonging to blood group $\mathrm{AB}$ in an accelerated manner, whereas grafts obtained from group $\mathrm{O}$ donors were rejected in first-set fashion (29). The present report describes responses to $94 \mathrm{ABO}$ blood group-compatible and incompatible skin allografts in 19 recipients pretreated with $\mathrm{ABO}$ group-compatible or incompati- ble erythrocytes, or with water-soluble A, B, and $\mathrm{O}(\mathrm{H})$ antigens. The results indicate that pretreatment with A or B erythrocyte group antigens in the form of erythrocytes, or as water-soluble substances, induces in blood group $\mathrm{O}$ recipients a state of hypersensitivity to skin allografts obtained from donors of the same incompatible erythrocyte group (A or B). This sensitivity is expressed in the recipients by the white graft or accelerated rejection of the $\mathrm{ABO}$-incompatible transplants. In contrast, skin grafts obtained from blood group $\mathrm{O}$ donors and applied to the recipients at the same time are accorded normal first-set survivals. The serum antibody responses observed in the recipients as a result of pretreatment and of subsequent challenge with skin allografts are described, with particular reference to their possible relationship to the types of graft responses observed.

\section{METHODS}

Selection of donors and recipients. Skin and erythrocyte donors and recipients were selected from a stable population of healthy volunteers known not to transmit homologous serum hepatitis on the basis of their previous records of blood and/or skin donations. These individuals were members of the panel of blood donor volunteers of the Institut de Recherches sur les Maladies du Sang, Laboratoire D'Immuno-Hématologie, Hôpital Saint-Louis, Paris, France. Complete erythrocyte, leukocyte, platelet, and serum group determinations were available for this entire panel.

Basic plan of experiment. (1) Six group $\mathrm{O}$ recipients were injected with $A_{2} B, A_{1}$, or $B$ erythrocytes. 2 wk later they were tested with skin grafts obtained from group $O, A_{1} B, A_{2} B, A_{1}$, and $B$ donors.

(2) Four group $A_{1}$ recipients were injected with $A_{1}$ erythrocytes and tested with group $O$ and group $A_{1}$ grafts 2 wk later.

(3) Five group $O$ recipients were injected intradermally with soluble A or B substances; they were tested 2 wk later with grafts from group $O$ donors, and with grafts obtained from group $A_{1}$ or $B$ donors, respectively. In addition, one group $A_{1}$ recipient was pretreated with soluble $B$ substance, and was then tested with grafts obtained from group $B$ and group $O$ donors. The final recipient in this series was a group $A_{1} B$ subject who was pretreated in similar fashion with $\mathrm{O}(\mathrm{H})$ substance, and was tested with grafts obtained from donors of blood groups $A_{1} B, B$, and $O$.

Earlier studies of allograft rejection responses in man have indicated that the usual first-set skin allograft survival time is $10-12$ days. In this study, as in previous reports, the accelerated (4-5 days) or white graft rejection of skin allografts have been interpreted as a manifestation of hypersensitivity of the host to the individualspecific and/or group-specific antigens present in the 
donors of such grafts. The white graft reaction has also been considered as an expression of a higher state of sensitivity than that expressed by graft rejection at 4-5 days $(30-38)$.

Materials used for pretreatment of recipients. Aliquots of blood were obtained from each donor. They were defibrinated in order to eliminate the blood platelets, and they were then freed of leukocytes by seven or eight successive sedimentations in Dextran (6\% solution, mol wt 200,000). No leukocytes were detectable in the majority of the final erythrocyte suspensions used; occasional lymphocytes were noted in some instances but they never exceeded $3000-4000$ cells in each preparation.

Soluble A substance was obtained from commercial sources. ${ }^{1}$ This material, extracted from hog gastric mucosa, was analyzed by Dr. Elvin A. Kabat of Columbia University. It contained 58 gamma $/ \mathrm{ml}$ of nitrogen; 295 gamma/ml of $N$-acetyl glucosamine; 136 gamma $/ \mathrm{ml}$ of galactose, and $94.5 \mathrm{gamma} / \mathrm{ml}$ of fucose. Soluble $\mathrm{O}(\mathrm{H})$ substance extracted from hog gastric mucosa in similar fashion, and containing the same nitrogen concentration was also obtained from Dr. Elvin A. Kabat. This material differs from soluble A substance only by the absence of the amino-sugar determinants present in A substance (39). Soluble B substance isolated from horse stomach lining was obtained from commercial sources (Knickerbocker Laboratories). Its composition has previously been described in detail by Baer, Kabat, and Knaub (40).

The final erythrocyte preparations were suspended in pyrogen-free isotonic saline solution, and were injected intradermally in divided doses of $0.1-0.2 \mathrm{ml}$, into the deltoid region of the shoulders of the recipients. The water-soluble $A, B$, and $O(H)$ substances were injected in similar volumes into the same regions. In those instances where intravenous injections of erythrocyte suspensions were employed, the latter were also resuspended in isotonic saline solution before injection.

Schedule of sensitization of the recipients. (1) Four group $\mathrm{O}$ recipients were injected with $\mathrm{A}_{2} \mathrm{~B}$ erythrocytes, given in 4 consecutive wk injections of $6.4-9 \times 10^{\circ}$ cells. The cells were injected intravenously in two recipients and intradermally in the other two individuals. 1 wk after the last injection, each subject received three skin allografts from $A_{1} B$ and $A_{2} B$ donors, and three grafts obtained from group $\mathrm{O}$ donors. Two other group $\mathrm{O}$ individuals received intravenous injections of similar amounts of group $A_{1}$ or of group $B$ erythrocytes, respectively. $1 \mathrm{wk}$ after the last injection, they were also tested with grafts obtained from three group $\mathrm{O}$ donors, and with grafts obtained from three group $A_{1}$ or group B donors, respectively.

(2) Four group $A_{1}$ individuals were pretreated in similar fashion with group $A_{1}$ erythrocytes, injected intravenously in two recipients, and intradermally in the other two instances. The erythrocyte doses used were similar to those used above. $1 \mathrm{wk}$ after the last injection, all recipients were tested with grafts obtained from the donor of the group $A_{1}$ erythrocytes, and with grafts ob-

1 Knickerbocker Laboratories, New York. tained from three other group $A_{1}$ individuals. Because of donor-recipient incompatibilities encountered in other erythrocyte and serum group antigens, this experiment also permitted an assessment of the role of the antigens $\mathrm{C}, \mathrm{Le}^{\mathrm{b}}, \mathrm{M}, \mathrm{N}, \mathrm{Fy}^{\mathrm{a}}, \mathrm{P}, \mathrm{S}$, and $\mathrm{Gm}^{\mathrm{b}}$ in influencing allograft responses under similar conditions.

(3) Seven individuals received intradermal injections of soluble blood group substances $A, B$, and $\mathrm{O}(\mathrm{H})$. The first four subjects received intradermal injections of soluble A substance. Two individuals (HOG and $B A R$ ) received $3 \mathrm{mg}$ of $A$ substance weekly for 4 consecutive wk, and were tested with skin grafts obtained from three group $\mathrm{O}$ donors and from three group $\mathrm{A}_{1}$ donors 1 wk later (i.e., 28 days after the first injection of A substance). A third subject (VAI) received the first two injections of A substance, but developed a massive inflammatory reaction at the injection site, which resulted in a reduction of his last sensitizing dose to 0.3 $\mathrm{mg}$ of A substance. The fourth subject (BAR) only received the first two doses of A substance (i.e., $6 \mathrm{mg}$ ) for similar reasons. Subjects VAI and BAR were both tested with grafts obtained from three group $O$ and three group $A_{1}$ donors at 28 days after the 1 st sensitizing injection.

Comparable amounts of $\mathrm{O}(\mathrm{H})$ substance were injected into a group $A_{1} B$ recipient, who was tested with three grafts obtained from $A_{1} B$ donors, two grafts obtained from $\mathrm{O}$ donors, and one graft obtained from a $\mathrm{B}$ donor, 28 days after the first injection of $\mathrm{O}(\mathrm{H})$ substance. Two other recipients were injected in similar fashion with soluble $B$ substance, including one individual of blood group $O$ (TIC), and one group $A_{1}$ recipient (FIL). Both subjects were tested with grafts obtained from three group $\mathrm{O}$ donors, and with grafts obtained from three group B donors, 28 days after the 1 st injection of $B$ substance.

\section{Methods of grafting and of graft observation}

The methods of grafting and of graft observation have been described in detail in previous publications $(30,32$, 34, 41). All grafts were full-thickness skin specimens measuring $11 \mathrm{~mm}$ in diameter, placed on the anterior surface of the forearms of the recipients. The transplants were observed daily; gross and stereomicroscopic criteria were employed for the diagnosis of graft rejection. Such criteria included cessation of blood flow and thrombosis in the superficial graft vessels, graft cyanosis, and edema, and the development of erythema and induration around the grafts (41). In the case of the white graft reaction, the absence of vascularization, dead white color of the grafts, and their evolution into a tan-colored eschar, provided the landmarks for recognition of this type of response (32).

Serologic Studies. Serum samples were obtained from the recipients before pretreatment, and at weekly intervals thereafter, until the 4 th wk after graft rejection. The sera were preserved at $-22^{\circ} \mathrm{C}$, and were inactivated at $56^{\circ} \mathrm{C}$ for $30 \mathrm{~min}$ before use. Each aliquot was tested for its anti-A and anti-B hemagglutinin titers by standard hemagglutination tests, utilizing $1 \%$ suspensions of hu- 
man blood group A and B erythrocytes. The hemagglutinin titers are presented in the tables and text as reciprocals of the highest serum dilution at which definite agglutination occurred. Parallel hemolysin titer determinations were also performed by standard techniques.

Selected serum samples were diluted to $1: 4$ and were incubated for $1 \mathrm{hr}$ at $37^{\circ} \mathrm{C}$ with equal volumes of $0.2 \mathrm{M}$ 2 -mercaptoethanol; they were then used immediately in hemagglutination tests (42). The immunoglobulin properties of high-titered antisera were also studied by sucrose density gradient ultracentrifugation (43). A volume of $0.5 \mathrm{ml}$ of selected serum samples, at a dilution corresponding to 32-64 agglutinating $\mathrm{U}$, was layered over a sucrose density gradient $(10-40 \%)$. Separation was performed in a swinging bucket rotor (Spinco ultracentrifuge) at $95,000 \mathrm{~g}$ for $16 \mathrm{hr}$. Successive fractions were obtained by the drop collection method, and were examined by hemagglutination tests against group $\mathrm{A}$ and $B$ erythrocytes after dialysis against saline.

\section{RESULTS}

(1) Pretreatment of group $O$ recipients with $A B O$-incompatible erythrocytes. As noted in Table I, 18 skin allografts obtained from blood group $\mathrm{O}$ donors were accorded first-set survival times (6-13 days) in recipients pretreated with $A_{2} B, A_{1}$, or $B$ erythrocytes. Skin grafts from group $A B\left(A_{1} B\right.$ or $\left.A_{2} B\right)$ donors were rejected in the same subjects as first-set grafts (6-8 days) in five instances, and in an accelerated manner (4-5 days) in three cases. Four other group $A B$ grafts were accorded white graft rejection. The white graft responses occurred in recipients pretreated intravenously with $\mathrm{A}_{2} \mathrm{~B}$ erythrocytes.

In similar fashion, recipients CHAL and PHIL, who had received $A_{1}$ and $B$ erythrocytes, respectively, rejected skin grafts obtained from other $\mathrm{A}_{1}$ and $\mathrm{B}$ donors in accelerated fashion (4-5 days).

(2) Pretreatment of group $A_{1}$ recipients with $A_{1}$ erythrocytes. The results of pretreatment of group $A_{1}$ recipients with $A_{1}$ erythrocytes are illustrated in Table II. This technique failed to sensitize the recipients to skin allografts obtained from the erythrocyte donors or from other group $A_{1}$ individuals. All grafts were rejected as first-set grafts (8.5-15 days). These results provide an additional control for possible effects of minute concentrations of leukocyte contaminants in the erythrocyte preparations used in this study. The first-set rejection of grafts obtained from the specific erythrocyte donors indicates that such leukocyte contaminants did not have a significant influ-

TABLE I

ERYTHROCYTE ANTIGENS IN HUMAN TRANSPLANTATION - EFFECTS OF PRETREATMENT OF GROUP O RECIPIENTS WITH ABO-INCOMPATIBLE ERYTHROCYTES

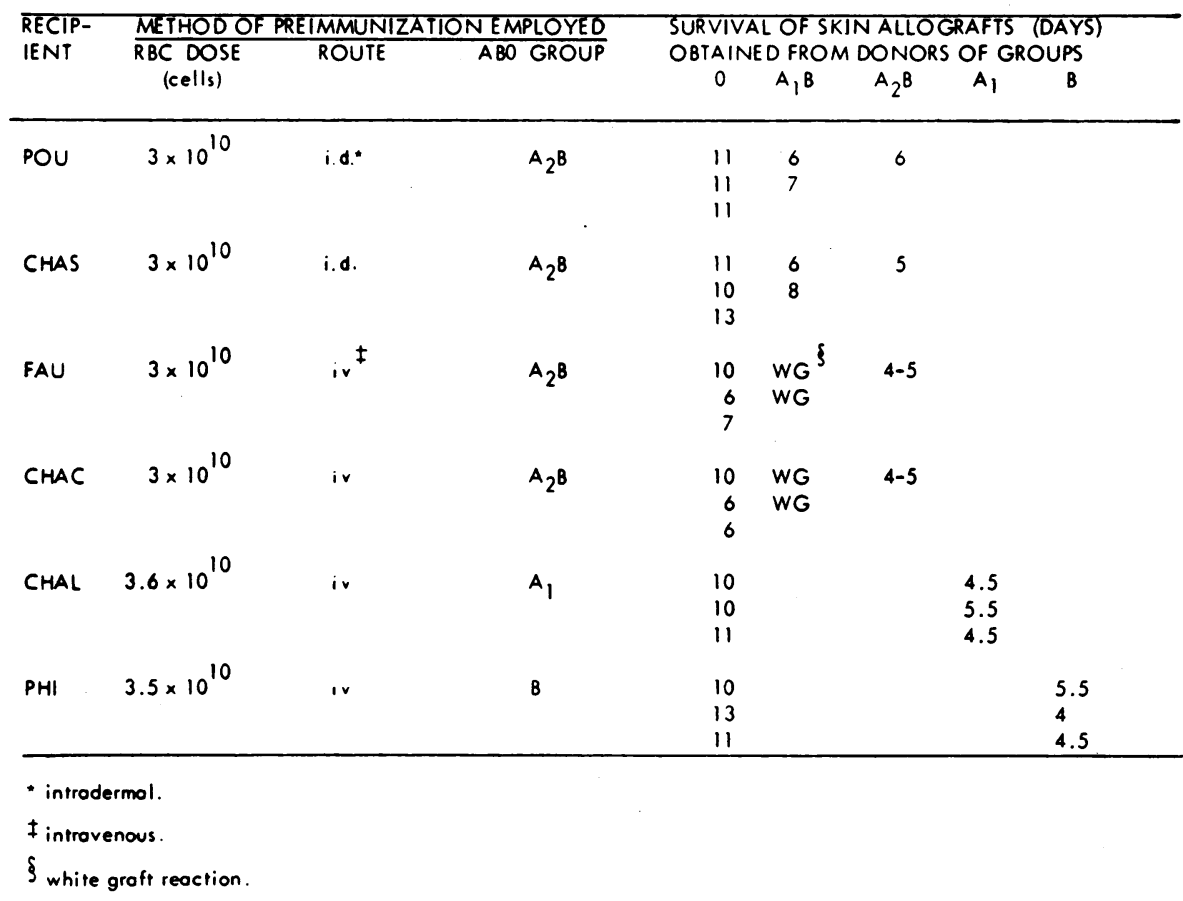


TABLE III

ERYTHROCYTE ANTIGENS IN HUMAN TRANSPLANTATION-EFFECTS OF PRETREATMENT OF A, RECIPIENTS WITH A, ERYTHROCYTES

\begin{tabular}{|c|c|c|c|c|c|c|c|c|c|}
\hline $\begin{array}{l}\text { RECIP- } \\
\text { IENT }\end{array}$ & DONORS & $\begin{array}{l}\text { ROUTE OF } \\
\text { IMUUNIZATION }\end{array}$ & $\begin{array}{c}\text { ERYTHROCYTE } \\
\text { DOSE } \\
\text { (cells) }\end{array}$ & $\begin{array}{r}\text { ERYTHI } \\
\text { INC } \\
\text { DC }\end{array}$ & $\begin{array}{l}\text { RO } \\
\text { ON } \\
\text { ON }\end{array}$ & $\begin{array}{l}\text { CYTE } \\
\text { PATI } \\
\text { ORS }\end{array}$ & $\begin{array}{l}\text { E OR SERUMG } \\
\text { IBILITIES BETW } \\
\text { AND RECIPIEN }\end{array}$ & $\begin{array}{l}\text { SROUP } \\
\text { VEEN } \\
\text { NTS }\end{array}$ & $\begin{array}{l}\text { SURVIVAL TIME OF A, SKIN } \\
\text { ALLOGRAFTS (DAYS) }\end{array}$ \\
\hline CHA & $\begin{array}{l}\text { FAU" } \\
\text { DRE } \\
\text { LHE } \\
\text { GOH }\end{array}$ & INTRAVENOUS & $4 \times 10^{10}$ & $\begin{array}{l}L_{e}^{b} \\
L e^{b} \\
L e^{a}\end{array}$ & E & $\begin{array}{l}c \\
c \\
c \\
c\end{array}$ & & & $\begin{array}{r}9 \\
9 \\
11 \\
10\end{array}$ \\
\hline LOU & $\begin{array}{l}\text { ORE* } \\
\text { LHE } \\
\text { FAU } \\
\text { GOH }\end{array}$ & INTRAVENOUS & $4 \times 10^{10}$ & $\begin{array}{l}L e^{b} \\
L e^{b}\end{array}$ & & & $\begin{array}{ll} & N \\
E & N \\
D & \end{array}$ & $\mathrm{Gm}^{0}$ & $\begin{array}{c}10 \\
- \\
11 \\
8.5\end{array}$ \\
\hline MOR & $\begin{array}{l}\text { LHE* } \\
\text { FAU } \\
\text { DRE } \\
\text { GOH }\end{array}$ & INTRADERMAL & $4 \times 10^{10}$ & $\operatorname{Le}^{\circ}$ & & & $\begin{array}{l}F y^{\circ} M \\
F y^{\circ} M \\
F y^{\circ} M \\
F y^{\circ} M\end{array}$ & & $\begin{array}{l}11 \\
15 \\
10 \\
12\end{array}$ \\
\hline GAU & $\begin{array}{l}\text { GOH' } \\
\text { LHE } \\
\text { FAU } \\
\text { DRE } \\
\end{array}$ & INTRADERMAL & $4 \times 10^{10}$ & $\begin{array}{l}L e^{b} \\
L e^{b}\end{array}$ & & & $\begin{array}{ll}p & S \\
P & S \\
P & S \\
& S\end{array}$ & $\begin{array}{ll}s & G m^{b} \\
s & G m^{b} \\
s & G m^{b} \\
s & G m^{b}\end{array}$ & $\begin{array}{c}9 \\
10 \\
11 \\
9\end{array}$ \\
\hline
\end{tabular}

- Donor of erythrocyte suspension used in pretreatment of the recipient.

TABLE III

ERYTHROCYTE ANTIGENS IN HUMAN TRANSPLANTATION-EFFECTS OF PRETREATMENT OF RECIPIENTS WITH SOLUBLE BLOOD GROUP SUBSTANCES

\begin{tabular}{|c|c|c|c|c|c|c|c|c|}
\hline \multirow[t]{2}{*}{ Recipient } & \multirow{2}{*}{$\begin{array}{l}\text { Blood } \\
\text { Group }\end{array}$} & \multicolumn{3}{|c|}{$\begin{array}{l}\text { Method of Preimmunization } \\
\text { Employed }\end{array}$} & \multicolumn{4}{|c|}{$\begin{array}{l}\text { Survival of skin ollografts (Days) obtained } \\
\text { from donors of groups }\end{array}$} \\
\hline & & $\begin{array}{l}\text { Soluble Blood Group } \\
\text { Substance Used }\end{array}$ & Route & Dose & 0 & $A_{1} B$ & $A_{1}$ & $\bar{B}$ \\
\hline HOG & 0 & A Substance & i.d. * & $12 \mathrm{mg}$ & $\begin{array}{l}14 \\
13 \\
14\end{array}$ & - & $\begin{array}{l}\text { white graft } \\
\text { white groft } \\
\text { white graft }\end{array}$ & - \\
\hline JAN & 0 & A Substance & i.d. & $12 \mathrm{mg}$ & $\begin{array}{l}9.5 \\
9 \\
11\end{array}$ & - & $\begin{array}{l}4 \\
4 \\
4\end{array}$ & - \\
\hline VAI & 0 & A Substance & i.d. & $9.3 \mathrm{mg}$ & $\begin{array}{l}12 \\
21.5 \\
13\end{array}$ & - & $\begin{array}{l}\text { white graft } \\
\text { white groft } \\
\text { white groft }\end{array}$ & - \\
\hline TIC & 0 & B Substonce & i.d. & $9 \mathrm{mg}$ & $\begin{array}{l}11 \\
12 \\
12\end{array}$ & - & - & $\begin{array}{l}\text { white groft } \\
\text { white groft } \\
\text { white graft }\end{array}$ \\
\hline FIL & $A_{1}$ & B Substance & i.d. & $9 \mathrm{mg}$ & $\begin{array}{l}8 \\
8.5 \\
10\end{array}$ & - & - & $\begin{array}{l}\text { white groft } \\
4.5 \\
\text { white groft }\end{array}$ \\
\hline $\mathrm{cOl}$ & $A_{1} B$ & H Substonce & i.d. & $6 \mathrm{mg}$ & $\begin{array}{l}10 \\
11.5\end{array}$ & $\begin{array}{c}7 \\
10 \\
8\end{array}$ & - & 9.5 \\
\hline
\end{tabular}

* i.d. = Intradermol. 
ence upon the results observed. Review of other erythrocyte and serum group incompatibilities present between the $A_{1}$ erythrocyte donors and the recipients studied here also indicates that group antigens $\mathrm{C}, \mathrm{Le}^{\mathrm{b}}, \mathrm{M}, \mathrm{N}, \mathrm{Fy}^{\mathrm{a}}, \mathrm{P}$, and $\mathrm{S}$ were inactive as transplantation antigens under these experimental conditions.

(3) Pretreatment of group $O, A_{1}$, and $A_{1} B$ recipients with soluble blood group substances. 42 grafts obtained from group $O, A_{1}, B$, and $A_{1} B$ donors were applied to seven group $O, A_{1}$, and $A_{1} B$ recipients after pretreatment with watersoluble $A, B$, or $\mathrm{O}(\mathrm{H})$ blood group substances, respectively. As noted in Table III, group $O$ recipients of $A$ substance rejected nine grafts obtained from group $A_{1}$ donors as white grafts; three other $A_{1}$ grafts were rejected in an accelerated manner (4 days). The 12 group $O$ grafts placed on the same recipients were accorded first-set survival times (7-22 days).

When two other recipients (group $\mathrm{O}$ subject TIC and group $A_{1}$ subject FIL) were tested with grafts obtained from group $\mathrm{B}$ and group $\mathrm{O}$ donors after pretreatment with soluble $B$ substance, the group B grafts were rejected as white grafts in five instances and in an accelerated manner ( $4-5$ days) in one case. The six group $\mathrm{O}$ grafts applied to the recipients were accorded first-set survival times (8-12 days).
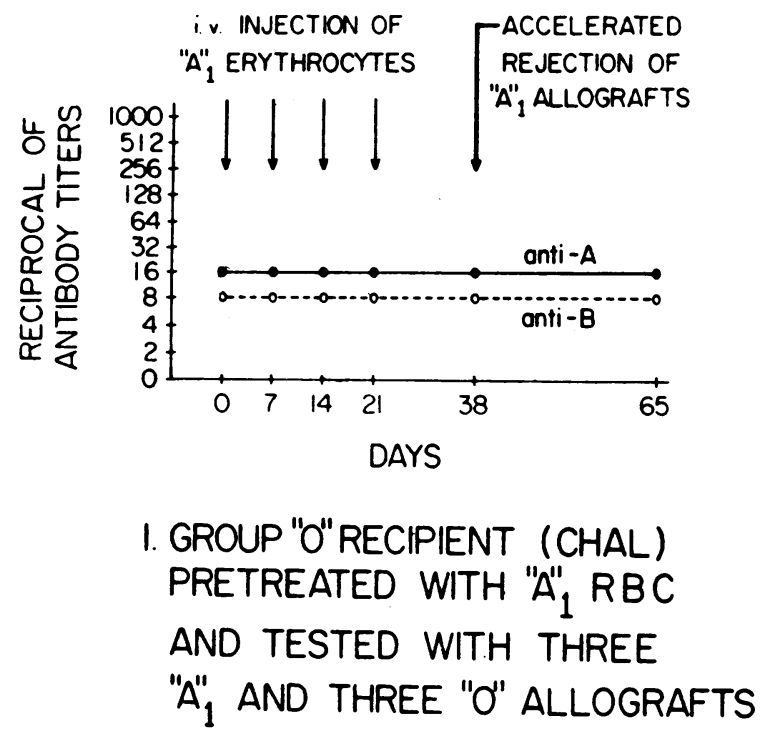

The final recipient was a group $A_{1} B$ individual (COL) pretreated with $\mathrm{O}(\mathrm{H})$ substance. This subject rejected three grafts from $A_{1} B$ donors, one graft from a group B donor, and two grafts from group $O$ donors as first-set grafts (7-11.5 days).

(4) Isoagglutinin titers in recipients of blood group antigens and skin allografts. Fig. 1 illustrates isoagglutinin titers observed in group $\mathrm{O}$ recipients pretreated with $A_{1}$ and $B$ erythrocytes and tested with group $O, A_{1}$ or $B$ skin allografts. None of the recipients developed any significant levels of anti-A or anti-B isoantibody. Pretreatment of group $O$ recipients with soluble $A$ substance, however, resulted in significant elevations in anti-A antibody titers (44). As noted in Fig. 2, two subjects received 4 consecutive wk $3 \mathrm{mg}$ doses of $A$ substance. The first recipient (JAN) had a preimmunization anti-A titer of 8 ; this rose to 1281 wk later, and was 64 at the time of the third injection of A substance. It remained at that level for the remainder of the study. JAN accorded accelerated rejection responses to three grafts obtained from $A_{1}$ donors. The second subject (HOG) had an anti-A titer of 64 before immunization; this rose to $5122 \mathrm{wk}$ after the first injection of $\mathrm{A}$ substance, and remained at that level while three group $A_{1}$ skin grafts were rejected as white grafts.

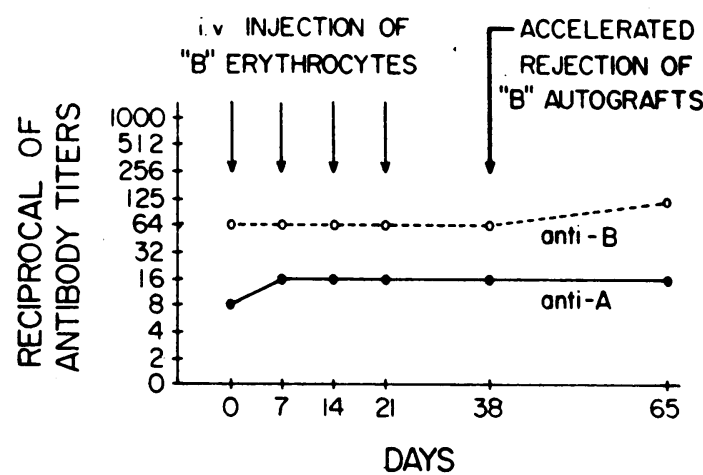

2. GROUP "O" RECIPIENT (PHIL) PRETREATED WITH "B" RBC AND TESTED WITH THREE "B" AND THREE "O" ALLOGRAFTS

FIGURE 1 Erythrocyte antigens in human transplantation. Serum antibody responses in recipients of ABO-incompatible erythrocytes. 

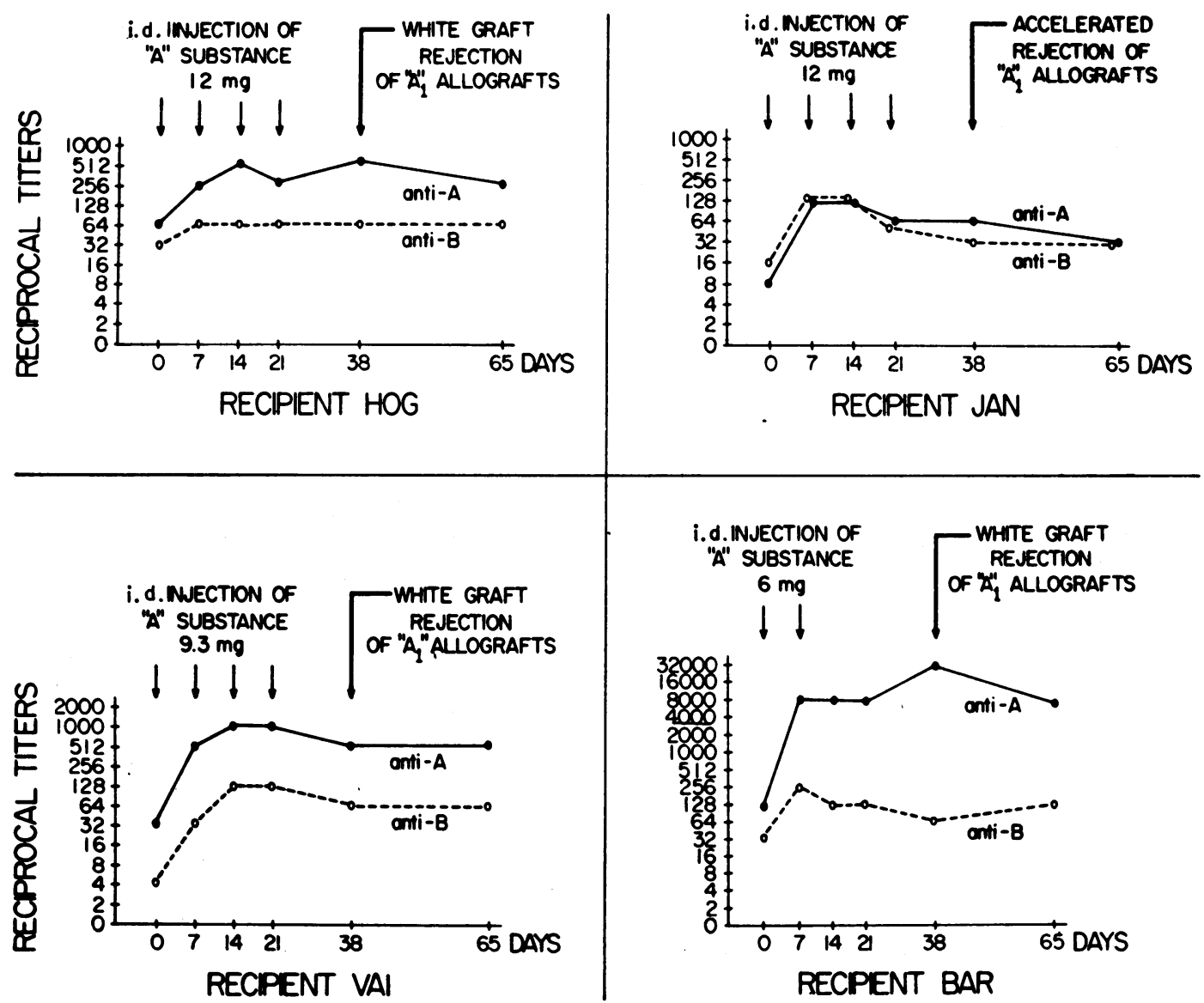

FIGURE 2 Erythrocyte antigens in human transplantation. Serum antibody responses in group "O" recipients of soluble " $A$ " substance.

Two other group $\mathrm{O}$ recipients were pretreated with smaller doses of $\mathrm{A}$ substance because of the local reactions induced by injection of this material. The presensitization anti-A titer of the first subject (VAI) was 32 ; it rose to $10242 \mathrm{wk}$ later. VAI received only $0.3 \mathrm{mg}$ of A substance on the 21 st day; the isoagglutinin titer was 512 at that time, and remained at this level at the time of white graft rejection of three group $A_{1}$ grafts. The second recipient (BAR) had a base line anti-A antibody titer of 28 ; this titer rose to 8192 within $1 \mathrm{wk}$. At this time, the second injection of A substance also evoked an intense inflammatory reaction, and pretreatment was discontinued. This subject's anti-A titer remained 8192 during the next $2 \mathrm{wk}$, and reached 32,778 at the time of white graft rejection of three skin transplants obtained from group $A_{1}$ donors. Moderate in- creases in anti-B antibody titers occurred in parallel with the anti-A responses described.

The isoagglutinin responses observed in recipients of B substance are illustrated in Fig. 3. Subject TIC (blood group O) whose base line anti-B antibody titer was 32 , received $9 \mathrm{mg}$ of $\mathrm{B}$ substance. The titer rose to $5122 \mathrm{wk}$ after the first injection of B substance, and was 1024 at the time of skin grafting. Three grafts obtained from B donors were rejected as white grafts by this recipient. At that time, his anti-B titer was 512 . TIC's anti-A antibody titer rose to 128 after the second injection of $B$ substance, and was 64 at the time of skin grafting and of graft rejection. The second recipient, FIL (blood group $A_{1}$ ) had an anti-B antibody titer of 2 before sensitization; it was 512 1 wk later, and rose to 1024 at the time of the last injection of $B$ substance. This subject accorded 

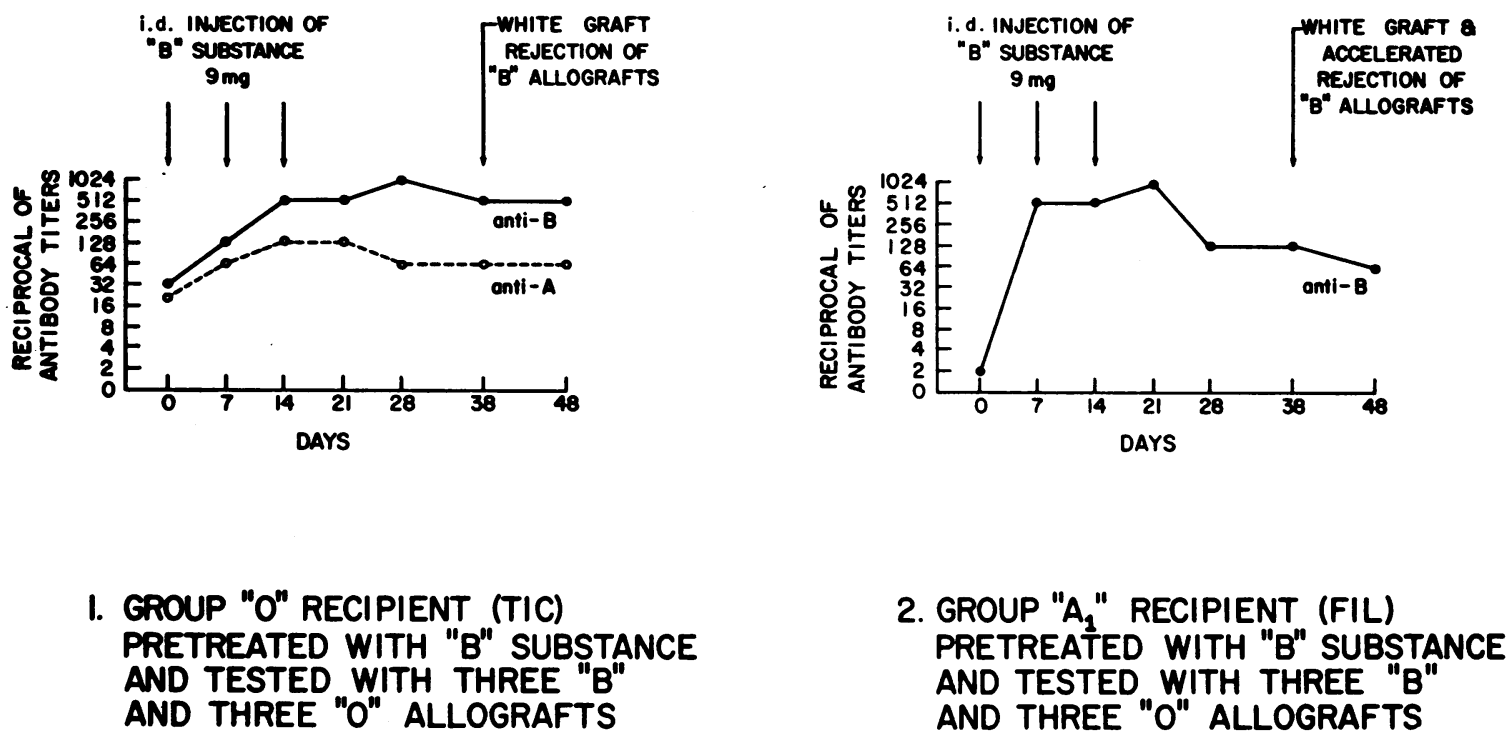

FigURE 3 Erythrocyte antigens in human transplantation. Serum antibody responses in recipients of soluble "B" substance.

white graft responses to two group B grafts, and an accelerated rejection response (4-5 days) to a 3 rd group $B$ graft. His anti-B antibody titer was 128 at that time. The anti-A and anti-B hemolysin titers paralleled these results.

Addition of 2-mercaptoethanol to selected serum samples did not significantly affect the anti-A or anti-B hemagglutinating activity of high-titer antisera. Sucrose density gradient ultracentrifugation of such sera indicated that their anti-A or anti-B hemagglutinating activity was localized to the IgG fraction. These results demonstrate that the serum antibody responses induced in recipients of soluble blood group substances were primarily of an IgG nature $(42,43)$.

\section{DISCUSSION}

The ability of blood group $\mathrm{O}$ recipients to reject in an accelerated manner skin grafts obtained from group $\mathrm{AB}, \mathrm{A}$, or $\mathrm{B}$ donors after pretreatment with erythrocytes of the corresponding group indicates that such erythrocytes can act as potent and group-specific transplantation antigens in man. Under the experimental conditions described, such erythrocytes have induced in the recipients a state of hypersensitivity to skin allografts similar to that observed after pretreatment of the host with donor-specific $(31,32,36,37)$ or group-specific $(33,34,45)$ transplantation antigens. The results suggest an experimental explanation for the decreased survival of kidney allografts transplanted across major ABO-incompatibility barriers (2127 ), and are in agreement with the report of Jacobson and Najarian (28) that treatment of dogs with group-incompatible erythrocytes may decrease the survival time of renal allografts in the recipients. The failure of group A recipients to accord accelerated rejection responses to skin grafts obtained from group A donors after pretreatment with group A erythrocytes lends further support to the concept that the type of allograft sensitivity induced by incompatible human erythrocytes may be of a group-specific, rather than an individual-specific character. This possibility is strengthened by the first-set survival time accorded by these recipients to skin grafts obtained from the specific erythrocyte donors.

The accelerated and/or white graft rejection of group $\mathrm{A}$ and $\mathrm{B}$ skin grafts in group $\mathrm{O}$ recipients pretreated with the corresponding soluble blood group substance illustrates the potential effectiveness of soluble antigens as transplantation antigens in man. The isolation and solubilization of biologically active extracts of mammalian transplantation antigens has become recognized as one of the most difficult problems in transplantation biology. The present study reports the existence of a type of water-soluble, heat-stable antigens capable of 
inducing strong allograft sensitivity in man. The implication of amino-sugars (glucosamine, galactosamine) as determinants of the $\mathrm{A}$ or $\mathrm{B}$ blood group specificity of such antigens (39) also suggests a potential approach to further studies of the biochemical specificity of the human trans. plantation antigens. The possible involvement of such determinants in conditioning responses of human recipients to allografts is strengthened by the observation that pretreatment of a group $A_{1} B$ recipient with $O(H)$ substance failed to affect his responses to skin grafts obtained from group $\mathrm{O}, \mathrm{A}_{1} \mathrm{~B}$, or $\mathrm{B}$ donors.

The ability of soluble antigens isolated from hog (A substance) and horse (B substance) stomachs to induce allograft sensitivity in man broadens the range of heterologous antigens implicated in the induction of mammalian transplantation responses. In this regard, the results may be pertinent to Brent, Medawar, and Ruszkiewicz's description of serologic cross-reactions between soluble A substance, pneumococcal polysaccharide, and the H-2 antigens of the mouse (46), and to the observation that group A streptococci and staphylococci can induce strong allograft sensitivity in rodents $(47-51)$. The results are also in harmony with the recent detection of heterophile hemagglutinins directed against sheep, guinea pig, and rat erythrocytes in recipients of human transplantation antigens (52).

The mechanisms responsible for the accelerated and/or white graft rejection of grafts obtained from group $\mathrm{A}, \mathrm{B}$, or $\mathrm{AB}$ donors in group $\mathrm{O}$ recipients of the corresponding incompatible erythrocyte group antigens are not clear at this time. Humoral agents would appear to be implicated by the apparent relationship between serum isoagglutinin levels and the incidence of white graft responses in recipients of soluble blood group substances, This interpretation is consonant with Wilson and Kirkpatrick's observation of a similar relationship between preformed anti-A and/or anti-B antibody titers in the host and the rapid rejection of ABO-incompatible renal allografts (26). It would also provide a possible explanation for the occasional white graft responses described in group $\mathrm{O}$ recipients of skin allografts obtained from group $\mathrm{A}$ donors in the absence of any obvious pretreatment (53). Indeed, the presence of blood group A substance in commercial peptones (39) has intro- duced this antigen as a contaminant in bacterial vaccines, toxoids, and other materials administered parenterally to human recipients. Such treatment may result in the development of significant antibody responses in individuals lacking this antigen (54), and may be related to the recipient's subsequent response to tissue transplants obtained from group A donors.

Involvement of cellular effector mechanisms in the allograft responses described in this report is suggested, however, by the absence of detectable serum isoantibody levels in some pretreated recipients who rejected blood group-incompatible grafts in an accelerated and/or white graft fashion. The possible role of cellular factors in this regard is also strengthened by the demonstration that leukocyte extracts obtained from specifically sensitized donors are capable of mediating individual-specific skin allograft rejection (accelerated rejection) in man (55).

It is possible, however, that the mechanisms of graft rejection operative under the present experimental conditions are not related to any of the types of allograft responses described previously. A definitive conclusion on these possibilities awaits the biological testing of the cellular and/or humoral factors associated with this type of response. The relative capacity of such factors to transfer ABO erythrocyte group-specific skin allograft sensitivity to normal recipients is currently under investigation.

\section{ADDENDUM}

Results described in this report were recently confirmed by Visetti, Scudeller, Leigheb, and Ceppellini. 1967. Importanza dei sottogrupp; $\mathrm{A}_{1}-\mathrm{A}_{2}$ e della reazion: crociate A-B per la sopravvivenza di alloinnesti di cute. Minerva Dermatol. 42: 563. These authors have also shown that $A_{1}$ is a stronger transplantation antigen than $A_{2}$, and that subjects sensitized with either soluble substance A or B could become cross-sensitized to skin allografts obtained from donors belonging to the other blood group. The latter observation is in keeping with the close structural similarities between A and B substances demonstrated by Kabat (39).

\section{ACKNOWLEDGMENTS}

The authors would like to express their deep gratitude for the kind help and advice of Dr. Elvin E. Kabat of Columbia University throughout this study. We also wish to acknowledge the high quality of the professional assistance rendered by Doctors Phillip R. Casson and 
Alex C. Solowey and the technical assistance of Mr. J. C. Poirier.

Dr. F. T. Rapaport is a Career Scientist of the Health Research Council of the City of New York, contract 1-349. This work was supported by a grant from The John A. Hartford Foundation, Inc., and supported in part by contracts $\mathrm{PH} 43-65-638$ and $\mathrm{PH} 43-65-986$ from the National Institute of Allergy and Infectious Diseases, National Institutes of Health, Bethesda, Md.

\section{REFERENCES}

1. Shawan, H. K. 1919. The principle of blood grouping applied to skin grafting. Am. J. Med. Sci. 157: 503.

2. Rogers, B. O. 1957. The genetics of skin homotransplantation in the human. Ann. N. Y. Acad. Sci. 64: 741.

3. Brown, J. B., and F. McDowell. 1942. Epithelial healing and the transplantation of skin. Ann. Surg. 115: 1166.

4. Woodruff, M. F. A., and T. M. Allan. 1953. Blood groups and the homograft problem. Brit. J. Plast. Surg. 5: 238.

5. Medawar, P. B. 1946 . Immunity to homologous grafted skin. II. The relationship between the antigens of blood and skin. Brit. J. Exptl. Pathol. 27: 15.

6. Medawar, P. B. 1959. Iso-antigens. In Symposium on Biological Problems of Grafting. F. Albert and G. Lejeune-Ledant, editors. Charles C Thomas, Springfield, Ill. 7.

7. Barrett, M. K., and W. H. Hansen. 1953. Resistance to tumor implantation induced by red cell stromata. Cancer Res. 3: 269.

8. Griffiths, C. O., and G. F. Crikelair. 1962. Isoimmunization following skin homografting in man. Nature. 193: 186.

9. Kuhns, W. J., F. T. Rapaport, H. S. Lawrence, and J. M. Converse. 1964. Serum antibody response to tissue transplantation antigens in man. Ann. N. $Y$. Acad. Sci. 120: 36.

10. Simonsen, M., and F. Sorensen. 1949. Homoplastic kidney transplantation in dogs. Acta Chir. Scand. 99: 61 .

11. Simonsen, M. 1953. Biological incompatibility in kidney transplantation in dogs. II. Serological investigations. Acta Pathol. Microbiol. Scand. 32: 36.

12. Simonsen, M., J. Buemann, A. Gammeltoft, F. Jensen, and $K$. Jorgensen. 1953. Biological incompatibility in kidney transplantation in dogs. I. Experimental and morphological investigations. Acta Pathol. Microbiol. Scand. 32: 1.

13. Hume, D. M., J. P. Merrill, B. F. Miller, and G. W. Thorn. 1955. Experiences with renal homotransplantation in the human: report of nine cases. J. Clin. Invest. 34: 327.

14. Hume, D. M. 1959. Experimental and clinical homotransplantation of kidney. In Transplantation of Tissues. L. A. Peer, editor. Williams \& Wilkins Co., Baltimore. 2: 484.

15. Hume, D. M., J. H. Magee, H. M. Kauffman, Jr., M. S. Rittenbury, and G. R. Prout, Jr. 1963. Renal homotransplantation in man in modified recipients. Ann. Surg. 158: 608.

16. Hume, D. M. 1965. Renal homotransplantation man: studies in 63 cases. In The Kidney. F. K. Mostofi and D. E. Smith, editors. Williams \& Wilkins Co., Baltimore. 409.

17. Hume, D. M. 1968. Kidney transplantation. In Human Transplantation. F. T. Rapaport and J. Dausett, editors. Grune and Stratton, Inc. 110.

18. Woodruff, M. F. A. 1960. The Transplantation of Tissues and Organs. Charles C Thomas, Springfield. 520.

19. Hamburger, J., J. Vaysse, J. Crosnier, J. Auvert, and J. Dormont. 1962. Kidney homotransplantation in man. Ann. N. Y. Acad. Sci. 99: 808.

20. Goodwin, W. E., M. M. Mims, and J. J. Kaufman. 1963. Human renal transplantation. III. Technical problems encountered in six cases of kidney homotransplantation. J. Urol. 89: 349.

21. Murray, J. E., and J. H. Harrison. 1963. Surgical management of fifty patients with kidney transplants including eighteen pairs of twins. Am. J. Surg. 105: 205.

22. Starzl, T. E., T. L. Marchioro, G., G. Hermann, R. S. Brittain, and W. R. Waddell. 1963. Renal homografts in patients with major donor-recipient blood group incompatibility. Surg. Forum. 14: 214.

23. Starzl, T. E. 1964. Patterns of permissible donorrecipient tissue transfer in relation to $A B O$ blood groups. In Experience in Renal Transplantation. T. E. Starzl, editor. W. B. Saunders Co., Philadelphia. 37.

24. Starzl, T. E., T. L. Marchioro, J. H. Holmes, G. Hermann, R. S. Brittain, O. H. Stonington, D. W. Talmage, and W. R. Waddell. 1964. Renal homografts in patients with major donor-recipient blood group incompatibilities. Surgery. 55: 195.

25. Starzl, T. E., T. L. Marchioro, J. H. Holmes, and W. R. Waddell. 1964. The incidence, cause, and significance of immediate and delayed oliguria or anuria after human renal transplantation. Surg. Gynecol. Obstet. 118: 819.

26. Wilson, W. E. C., and C. H. Kirkpatrick. 1964. Immunological aspects of renal homotransplantation. In Experience in Renal Transplantation. T. E. Starzl, editor. W. B. Saunders Co., Philadelphia. 239.

27. Gleason, R. E., and J. E. Murray. 1967. Report from Kidney Transplant Registry: Analysis of variables in the function of human kidney transplants. I. Blood group compatibility and splenectomy. Transplantation. 5: 343 .

28. Jacobson, E., Jr., and J. S. Najarian. 1964. Role of the red blood cell antigens in homograft rejection. Surg. Forum. 15: 138.

29. Dausset, J., and F. T. Rapaport. 1966. The role of ABO erythrocyte groups in human histocompatibility reactions. Nature. 209: 209.

30. Converse, J. M., and F. T. Rapaport. 1956. The vascularization of skin autografts and homografts. An experimental study in man. Ann. Surg. 143: 306. 
31. Rapaport, F. T., and J. M. Converse. 1957. Observations on immunological manifestations of the homograft rejection phenomenon in man: the recall flare. Ann. N. Y. Acad. Sci. 64: 836.

32. Rapaport, F. T., and J. M. Converse. 1958. The immune response to multiple-set skin homografts: an experimental study in man. Ann. Surg. 147: 273.

33. Rapaport, F. T., L. Thomas, J. M. Converse, and H. S. Lawrence. 1960. The specificity of skin homograft rejection in man. Ann. N. Y. Acad. Sci. 87: 217.

34. Rapaport, F. T., H. S. Lawrence, L. Thomas, J. M. Converse, W. S. Tillett, and J. H. Mulholland. 1962. Cross-reactions to skin homografts in man. J. Clin. Invest. $41: 2166$.

35. Rapaport, F. T., and J. M. Converse. 1964. Skin transplantation immunity in man. In Reconstructive Plastic Surgery. J. M. Converse, editor. W. B. Saunders Co., Philadelphia. 2131.

36. Rapaport, F. T., H. S. Lawrence, J. M. Converse, and J. H. Mulholland. 1964. Homograft antigen studies in man. Ann. N. Y. Acad. Sci. 120: 280.

37. Rapaport, F. T., J. Dausset, J. M. Converse, and H. S. Lawrence. 1965. Biological and ultrastructural studies of leucocyte fractions as transplantation antigens in man. Transplantation. 3: 490.

38. Rapaport, F. T., J. Dausset, J. M. Converse, and H. S. Lawrence. 1965. Transplantation immunity studies in man. In Histocompatibility Testing. N.A.S.NRC., Washington, D. C., Public. 1229, p. 97.

39. Kabat, E. A. 1956. Blood group substances. Academic Press, Inc., New York.

40. Baer, H., E. A. Kabat, and V. Knaub. 1950. Immunochemical studies on blood groups. $\mathrm{X}$. The preparation of blood group A and B substances and on inactive substance from individual horse stomachs and of blood group B substance from human saliva. J. Exptl. Med. $91: 105$.

41. Rapaport, F. T. 1965. General description of method of grafting and of graft observation of human subjects. In Histocompatibility Testing, N.A.S.-N.R.C., Washington, D. C., Public. 1229, p. 185.

42. Scheidegger, J. J. 1955. Une micro-méthode de l'immuno-électrophorèse. Intern. Arch. Allergy Appl. Immunol. $7: 103$.

43. Fudenberg, H. H., and H. G. Kunkel. 1957. Physical properties of the red cell agglutinins in acquired hemolytic anemia. J. Exptl. Med. 106: 689.
44. Witebsky, E., N. C. Klendshoj, and C. McNeil. 1944. Potent typing sera produced by treatment of donors with isolated blood group specific substances. Proc. Soc. Exptl. Biol. Med. 55: 167.

45. Dausset, J., and F. T. Rapaport. 1966. The role of blood group antigens in human histocompatibility. Ann. N. Y. Acad. Sci. 129: 408.

46. Brent, L., P. B. Medawar, and M. Ruszkiewicz. 1961. Serological methods in the study of transplantation antigens. Brit. J. Exptl. Pathol. 42: 464.

47. Rapaport, F. T., and R. M. Chase, Jr. 1964. Homograft sensitivity induction by group A streptococci. Science. 145: 407.

48. Chase, R. M., Jr., and F. T. Rapaport. 1965. The bacterial induction of homograft sensitivity. I. Effects of sensitization with Group A streptococci. J. Exptl. Med. 122 : 721.

49. Rapaport, F. T., and R. M. Chase, Jr. 1965. The bacterial induction of homograft sensitivity. II. Effects of sensitization with staphylococci and other microorganisms. J. Exptl. Med. 122: 733.

50. Rapaport, F. T., and R. M. Chase, Jr. 1965. Transplantation antigen-like activity of streptococcal cells. In Conference on Histocompatibility Testing. Munksgaard, Copenhagen. 171.

51. Rapaport, F. T., R. M. Chase, Jr., and A. C. Solowey. 1966. Transplantation antigen activity of bacterial cells in different animal species and intracellular localization. Ann. N. Y. Acad. Sci. 129: 102.

52. Rapaport F. T., J. Dausset, J. Hamburger, D. M. Hume, K. Kano, G. M. Williams, and F. Milgrom. 1967. Serologic factors in human transplantation. Ann. Surg. 166: 596.

53. Ceppellini, R., E. S. Curtoni, P. L. Mattiuz, G. Leigheb, M. Visetti, and A. Colombi. 1966. Survival of test skin grafts in man: effect of genetic relationship and of blood groups in compatibility. Ann. N. Y. Acad Sci. 129: 421.

54. Dausset, J., and G. Vidal. 1951. Accidents de la transfusion chez des receveurs de groupe $A$ ayant recu du sang de groupe $O$. Rôle de la vaccination par l'anatoxine diphterique et tetanique. Sang. 22: 478.

55. Lawrence, H. S., F. T. Rapaport, J. M. Converse, and W. S. Tillett. 1960. Transfer of delayed hypersensitivity to skin homografts with leucocyte extracts in man. J. Clin. Invest. 39: 185. 